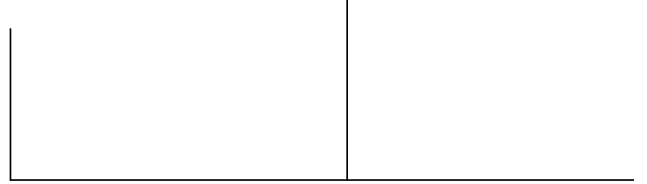

Rev. Latinoam. Psicopat. Fund., V, 1, 186-188

“Aspectos genéticos do transtorno de pânico"

Guilherme Peres Messas e Homero Pinto Vallada Filho Revista de Psiquiatria clínica, vol. 28, n. 1, p. 12-5, 2001 Resenhado por: Marcos Romano Bicalho

\title{
O transtorno de pânico visto pelo ângulo da genética
}

For every complex problem there is a simple solution which is wrong. George Bernard Shaw

Vivemos uma onda dos estudos biológicos na psiquiatria. A genética tem caminhado para ocupar um importante espaço nestas pesquisas. Trata-se de uma ferramenta interessante; uma área que representa um enorme desafio para os cientistas. Quando os pesquisadores decidem procurar por genes que causam uma doença mental - por exemplo, o transtorno de pânico - tudo o que eles sabem é que este quadro tem um componente hereditário interferindo na susceptibilidade do indivíduo a manifestá-lo e que um ou mais de nossos aproximadamente 80.000 genes devem mediar essa herança. Porém, não é factível examinar um por um desses genes, mesmo que a pesquisa se limitasse aos cerca de 30.000 genes expressos no cérebro humano. Não bastasse isto, os genes constituem apenas $2 \%$ dos 3 bilhões de pares de bases de DNA de nossos cromossomos (FARAONE et al., 1999). É a verdadeira situação de se procurar uma agulha no palheiro.

Não obstante isto, não podemos nos furtar a trilhar o terreno ventureiro. Precisamos incrementar os debates em nosso meio para ganharmos confiança no desenvolvimento de conhecimentos na área. O artigo de Messas e Vallada Filho é bastante oportuno neste sentido. Ter encontrado autores nacionais interessados no assunto foi uma satisfação.

A breve revisão dos autores nos posiciona, ainda que parcialmente, sobre o estado atual de entendimento da genética do transtorno de pânico. Vale 
lembrar que este transtorno oferece uma condição bastante particular para os estudos genéticos, pois situa-se numa região de fronteira entre as alterações orgânicas e as psíquicas. A opção pela forte concisão do texto excluiu considerações importantes. Entretanto, se a tentativa de síntese resultou em certas perdas, teve o mérito de oferecer elementos objetivos para o debate na escassa literatura nacional. Devemos valorizar aqueles que estão se dedicando à tarefa tão interessante e importante como a genética psiquiátrica e assim incentivar as discussões.

Os autores optaram por uma seqüência didática, ilustrando bem o caminho que se faz em genética. Mostraram que o processo começa por verificar a ocorrência do transtorno de pânico nas famílias (forte ocorrência), seguindo para estudos com gêmeos (taxa de concordância em monozigóticos significativamente maior do que em dizigóticos) e testes quanto aos modelos de transmissão (incerto até o momento). Dado que o transtorno de pânico apresenta evidências de componente genético em sua etiologia, parte-se para estudos moleculares, com o intuito de abrir portas para a compreensão da fisiopatologia da afecção. As referências do artigo são as mais relevantes para conhecermos o "caminho das pedras” da pesquisa genética sobre o pânico.

A genética tem se ampliado tanto nos últimos anos que quatro subáreas assumiram praticamente um caráter de independência de pesquisa: a) genética de populações; b) genética de transmissão; c) genética molecular e d) genética do desenvolvimento. $\mathrm{O}$ fato de não haver menção da última deixou uma lacuna na revisão, uma vez que já existem pesquisas que buscam estudar os fatores de risco e as influências do meio no desenvolvimento do transtorno de pânico. São estudos promissores, alguns prospectivos (p.ex. Noyes et al., 1993), outros evidenciam a interação dos genes com o ambiente (p.ex. CADORET et al., 1983), abrindo perspectivas diferentes para a reformulação dos modelos explicativos, a qual configura-se como uma demanda evidente devido ao fato, como o texto deixa claro, de o transtorno de pânico apresentar uma complexa heterogeneidade etiológica. Para aqueles interessados em ter uma idéia de uma análise recente dos fatores de risco, recomendamos o excelente artigo de Kraemer et al. (2001).

Infelizmente, como nos mostram Messas e Vallada Filho, as tentativas de localizar os genes implicados na etiologia do transtorno de pânico resultaram negativas até o momento. Novas técnicas estão sendo testadas, sendo que os autores limitaram-se a citar a técnica das associações alélicas, deixando o leitor curioso a respeito das inovações como as tentativas de varredura do genoma (KNowles et al., 1998).

Como os autores pretenderam uma revisão, cabe comentar um aspecto que deveria aparecer numa tal empreitada, qual seja, a problemática das categorias diagnósticas (foi apenas citada a questão problemática do status nosológico da agorafobia). Em vários trabalhos na literatura internacional há uma preocupação tanto 
com a inadequação das classificações, quanto com os métodos clínicos utilizados para identificar os indivíduos afetados e a condição de seus familiares. Discussões neste terreno seriam as mais bem-vindas para o avanço dos estudos da genética e da psicopatologia do transtorno de pânico. A revisão de van den Heuvel et al. (2000) ilustra bem a relevância destas questões.

Por outro lado, um artigo breve como este permitirá ao clínico estudioso ter uma visão panorâmica do assunto sem se perder em minúcias dos especialistas. O texto motiva-nos a estudar mais sobre genética.

Os autores, ao final, são otimistas quanto ao futuro das investigações da genética psiquiátrica, mesmo diante de contexto nada animador. Fica aqui também a esperança, em recomendando este artigo, de haver mais discussões sobre o alcance, os benefícios e as repercussões na psicopatologia a partir dos investimentos em genética psiquiátrica.

\section{Referências}

Cadoret, R.J.; Cain, C.A.; Crowe, R.R. Evidence for gene-environment interection in the development of adolescent antisocial behavior. Behahavior Genetics, v. 13, n. 3, p. 301-10, 1983.

Faraone, S.V.; Tsuang, M.T.; Tsuang, D.W. Genetics of Mental Disorders. Nova York: The Guilford Press, 1999.

Van den Heuvel, O.A.; Van den de Wetering, B.J.M.; Veltman, D.J.; Pauls, D.L. Genetic studies of panic disorder: a review. J Clin Psychiatry, v. 61, n. 10, p. 756-66, 2000.

KNowles, J.A. et. al. Results of a genome-wide genetic screen for panic disorder. Am. J. Med. Genet., n. 81, p. 139-47, 1998.

Kraemer, H.C. et al. How risk factors work together? Mediators, moderators, and independent, overlapping and proxy risk factors. Am. J. Psychiatry, v. 158, n. 6, p. 848-56, 2001.

Noyes, Jr. et al. Environmental factors related to the outcome of panic disorder: a sevenyear follow-up study. J. Nerv. Ment. Dis., v. 181, n. 9, p. 529-38, 1993.

Pereira, M.E.C. Genética e subjetividade: o paradigma dos estados maníaco-depressivos. Revista da APPOA, Porto Alegre, n. 21, p. 75-90, dez./2001. (Os nomes da tristeza) 